\title{
On the Translation of Founding Narratives into Cartographic Images: America in Le Testu's Cosmographie Universelle (1556)
}

\author{
Carolina Martínez \\ CONICET - LICH, National University of General San Martín \\ e-mail: carolina.martinez@unsam.edu.ar \\ ORCID iD: https://orcid.org/0000-0002-5692-0995
}

Submitted: 3 February 2020. Accepted: 12 December 2020.

\begin{abstract}
This article analyzes the links between the first travel accounts of the New World and the production of cartographic images of America in Guillaume Le Testu's Cosmographie Universelle (1556). Produced in 1556 and dedicated to Admiral of France Gaspard de Coligny, the Norman pilot's manuscript atlas was created in the context of growing French colonial interest in Terra Brasilis. The transposition of America's founding narratives into cartographic images as presented in Le Testu's Cosmographie is interpreted here as an act of translation lato sensu. The translation of the continent's travel accounts in the strictest sense of the word, and the adaptation of New World information to new audiences and political contexts are also examined in the analysis of this manuscript nautical atlas.
\end{abstract}

KEYWORDS: Cartography; Cosmography; Maps; Early Modern; America; Guillaume Le Testu; Overseas Expansion; France; Translation.

Citation / Cómo citar este artículo: Martínez, Carolina (2021) "On the Translation of Founding Narratives into Cartographic Images: America in Le Testu's Cosmographie Universelle (1556)." Culture \& History Digital Journal, 10 (2): e017. https://doi.org/10.3989/chdj.2021.017

RESUMEN: Sobre la traducción de relatos fundacionales en imágenes cartográficas: América en la Cosmographie Universelle (1556) de Guillaume Le Testu._El artículo analiza el vínculo entre los primeros relatos de viaje al Nuevo Mundo y la producción de imágenes cartográficas sobre América en la Cosmografía Universal del piloto normando Guillaume Le Testu. Dedicado al Almirante de Francia Gaspard de Coligny en 1556, el atlas manuscrito se produjo en un contexto de auge de los proyectos colonizadores franceses en Terra Brasilis. La transposición de los relatos fundacionales americanos en imágenes cartográficas tal como se presenta en el caso de Le Testu es interpretada como un acto de traducción en sentido amplio. A su vez, la traducción de los relatos de viaje en sentido estricto y la adaptación de las informaciones americanas a nuevos públicos y contextos políticos completan el estudio del atlas náutico manuscrito.

PALABRAS CLAVE: Cartografía; Cosmografía; Mapas; Modernidad temprana; América; Guillaume Le Testu; Expansión ultramarina; Francia; Traducción.

Copyright: () 2021 CSIC. This is an open-access article distributed under the terms of the Creative Commons Attribution 4.0 International (CC BY 4.0) License. 


\section{AN IMAGE IN A SET OF COORDINATES: AMER- ICA IN LE TESTU'S COSMOGRAPHIE UNIVER- SELLE (1556)}

In April 1556, the Norman pilot and cartographer Guillaume Le Testu dedicated a richly hand-colored cosmographic manuscript to Admiral of France Gaspard de Coligny. Le Testu's in-folio Cosmographie Universelle contains a total of fifty-six maps, of which six are cartographic projections of the whole globe. ${ }^{1}$ The remaining fifty cartographic images depict known, unknown or partially explored regions of the world. In Le Testu's cosmography, the maps of Europe, Africa and Asia co-exist with those of Terra Australis and the New World. ${ }^{2}$ Although much of America was still unknown to European explorers at the time, Le Testu devoted fifteen of his manuscript maps to representing the continent, its nature and its inhabitants. At first glance, the precision with which America's coasts are outlined points to the influence of Portuguese mapmakers and their early representations of Terra Brasilis (Lestringant, 1991, p. 245; 2013, p. 96). A closer look at the iconography displayed on the maps of Pars Quarta ${ }^{3}$ and the texts that accompany them, however, shows that Le Testu was also likely influenced by the accounts of the initial Spanish explorations of Peru, New Spain and Patagonia, as well as the French voyages to Canada undertaken during the same period, which he explicitly mentions when describing the area (Le Testu, 1556, Folio LVIII recto). Indeed, information about these lands, which Le Testu himself acknowledges were unknown to ancient geographers, was available in the travel accounts of contemporary voyagers, whose descriptions Le Testu most likely transformed into cartographic images in his nautical atlas. ${ }^{4}$

As Jean-Marc Besse has stated, it was in the early modern period that the cosmographic genre proved to be an epistemological device apt to inscribe and represent incoming geographic information. In the context of European overseas maritime expansion, its new object of study was an enlarged ecumene or inhabited portion of the earth, which had to be studied and described as never before (Besse, 2003a, p. 152). ${ }^{5}$ Thus, the cosmographer's task was to collect, select and organize a set of heterogeneous and disperse data, in order to make it comprehensible to a larger audience and account for the different terrestrial realities European navigators were confronted with (p. 156). After all, geography was and still is "an art of representation, that is to say, an art of transport and translation" (Besse, 2003b, p. 9). The formal structure and topics of a more descriptive approach to the cosmographic genre (in line with Strabo's geography) were to be defined in 1544, when Sebastian Münster published his Cosmographiae Universalis. ${ }^{6}$ Despite the visible differences between the published and manuscript versions of the genre, as is the case of Münster's and Le Testu's works, all cosmographers had to depend on external sources of information to describe the territories they were not able to explore or depict for themselves.

That being said, the iconographic repertoire of the Cosmographie's fifteen maps of America sheds light on the circulation of New World knowledge in Europe as well as on the relationship between text and image in early modern mapmaking.? This article examines this passage from literature to cartographic image in the specific case of the production of Le Testu's 1556 nautical atlas in the context of the early modern exploration of the New World. The analysis of Le Testu's Cosmographie will focus on the transposition from text to image, which this article interprets as an act of translation lato sensu. As will be shown, akin to other manuscript or printed early modern maps (Van Duzer, 2015, p. 51; Davies, 2016, p. 128), ${ }^{8}$ the Cosmographie synthesizes the information and textual images enclosed in the first travel accounts of America to produce cartographic motifs. These images, which in the case of France were produced in commercially relevant regions such as the Norman ports of Dieppe and Le Havre, were intended to circulate within particular audiences and be "read" in specific political and social contexts. Studying the act of translating novel American information into cartographic images as evidenced in Le Testu's Cosmographie Universelle will, in turn, allow us to discern the criteria dictating the selection of the travel accounts that were consulted for its production.

Last but not least, this analysis of Le Testu's Cosmographie will elucidate the methodological challenges faced by early modern cartographers in their representation of America as Pars Quarta. As I shall demonstrate, the influence of founding American narratives on the production of cartographic images was especially important throughout the multifaceted process by which the continent was reckoned as a fourth part of the known world (Martínez, 2019). The synthesis of multiple travelers' accounts into visual forms as evidenced on the period's maps represent some of America's foundational expressions. As the examination of Le Testu's maps will show, the first-hand descriptions present in America's founding travel accounts were interpreted and turned into long-lasting visual motifs which were unequivocally associated with Pars Quarta on sixteenth century manuscript maps and beyond.

From a methodological perspective, it is worth considering why the passage from text to image should be interpreted as an "act of translation." In the broadest sense of the word, as William F. Hanks and Carlo Severi have stated, we constitute our objects and make claims about them by means of translation $(2015$, p. 2). According to both anthropologists, "understanding is itself a matter of translation," since "the object understood is translated into some variety of interpretant or representation on the part of the understander" $(2015$, p. 3). This means, on the one hand, that translation is not merely language oriented. As Hanks and Severi pose, cultural traditions also present a variety of nonlinguistic forms of translation: "words are translated into images, music into words, and gestures into objects" (2015, p. 10). On the other hand, it is possible to infer that any act of translation is intended to transmit and interpret what is produced in a certain language or cultural context into another language or for another audience.

In Le mirroir d'Herodote. Essai sur la représentation de l'autre, François Hartog has referred to this act of trans- 
On the Translation of Founding Narratives into Cartographic Images: America in Le Testu's Cosmographie Universelle (1556) 3

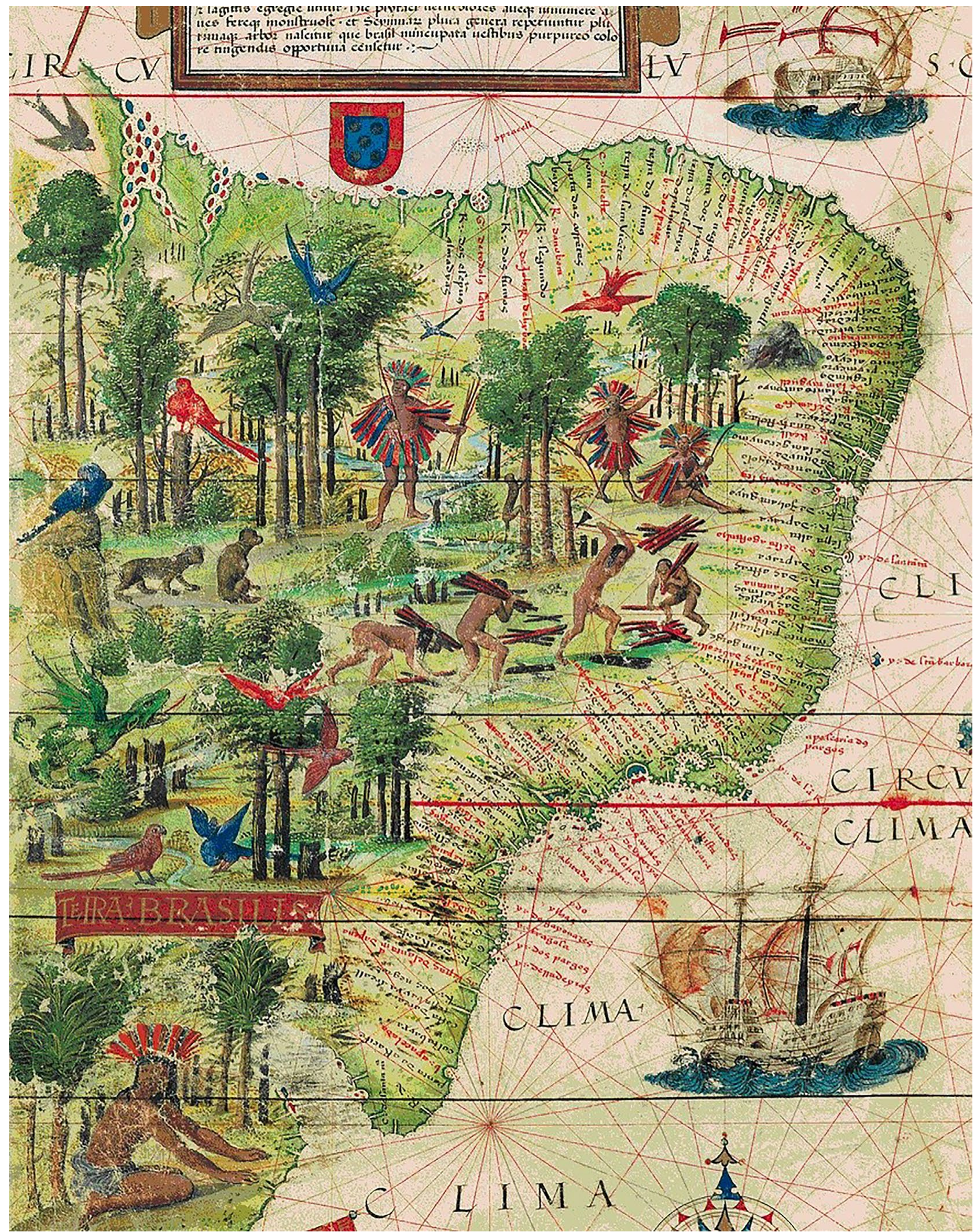

Figure I. Lopo Homem, Atlas nautique du Monde, dit atlas Miller, 1519. Illuminated manuscript, 42 x $59 \mathrm{~cm}$. Detail of folio 5 . Bibliothèque Nationale de France Département Cartes et plans, GE DD-683 (5 RES). 
mission as a means of making the "other" understandable in terms of one's own culture (1988, p. XXIV). According to Hartog, "a narrator who belongs to group $a$ tells the people of $a$ about $b$; there is one world in which one recounts, another that is recounted. How can the world being recounted be introduced in convincing fashion into the world where it is recounted? That is the problem facing the narrator: a problem of translation" (1988, p. 212). The "rhetoric of otherness," which the French historian considers an operation of translation, is thus identified as a possible solution. In the case of early modern travel accounts, the use of a set of rhetorical figures allowed authors "to convey the "other' to the "same" (p. 237), thus making the New World intelligible to the inhabitants of the Old. The act of translating as interpreted by Hartog is therefore a good starting point to reflect on the applicability of the term across other genres and materials, not only between the Old and New worlds but also within the Old world itself. After all, cartographic motifs based on the descriptions present in the travel accounts of Vespucci and Pigafetta or in the Spanish chronicles that circulated throughout Europe in the mid-sixteenth century might well be considered acts of interpretation and, in this sense, of cultural translation.

As Christian Jacob asserts in his examination of the 1519 Miller Atlas (Fig. 1), ${ }^{10}$ apart from "providing information aimed at the navigator," early modern maps also condensed and included "more general information of a geographical, historical, or ethnographic nature" in their images (Jacob, 2006, p. 167). In line with the content of the Miller Atlas and the images portrayed on Vicenzo Coronelli's 1683 terrestrial globe, this article proposes that the images present on Le Testu's maps of America were the outcome of a conscientious process of selection and appropriation in which the images' political context of production was a determining factor. If, as Jacob argues, "the image illustrates a preexisting description or narrative" (Jacob, 2006, p. 168), then the transposition of New World information into cartographic images in a period of inter-oceanic competition should be studied as an act of cultural translation tailored to different contexts of reception.

Regarding the Cosmographie's historical origins in particular, the images present on the pilot's fifteen maps of America must also be examined in the context of the first French colonial exploits in America. In a period dominated by the Spanish conquest of pre-Columbian political centers such as the Mexican and Andean regions, the occupation of marginal territories became an objective of Spain's European counterparts (Gandini et al., 2013). Le Testu presented his manuscript atlas to Gaspard de Coligny at a time when in spite of the pre-existing Portuguese territorial claims in America, the French monarchy was actively seeking to establish itself on the shores of Terra Brasilis (Pagden, 1997, pp. 89, 110). ${ }^{11}$ The nature of Gallic colonial ventures meant that the Crown depended on the port cities of northern France and on Norman financiers in particular, who, in turn, relied on the Crown's protection if attacked by foreign maritime powers.
Throughout the sixteenth century, Normandy was the center of French maritime trade. Norman armateurs or ship-owners financed overseas commercial ventures which often counted on the king's consent and support. The development of a "school" of cartography in this region was a logical consequence of these maritime activities. According to Sarah Toulouse, although it was not necessarily an established "school," "the term refers to a group of cartographers who worked together using the same techniques and resources and whose maps were similar to each other" (Toulouse, 2007, p. 1550). ${ }^{12}$ In the early sixteenth century, the newly founded city of Le Havre (1517) as well as those of Dieppe and Honfleur were the ports of departure for most of the French expeditions to America, as well as the points of arrival for Portuguese cartographers willing to offer their services to other crowns. ${ }^{13}$ The gift of Le Testu, who was born in Le Havre, is therefore representative of the interdependency of the port cities of northern France and the French Crown. Technically speaking, the manuscript also illustrates the influence foreign cartographic expertise exerted on local map making. The impact of Portuguese cartography on Norman maps is evident in the nomenclature of the cities and in other geographical features, as well as in the layout of the coasts (Van Duzer, 2015, p. 16). ${ }^{14}$ In fact, as far as style is concerned and despite its singularities, the Norman "school" of cartography owes much to the work done by Portuguese mapmakers in the first few decades of European exploration. ${ }^{15}$ For example, a brief comparison between the map of Brazil made by Portuguese cartographer Lopo Homem and the Reinel family circa 1519 (Fig. 1) and Le Testu's chart of the region (Fig. 2) shows clear resemblances in coloring and style. ${ }^{16}$

Concerning the content of the Cosmographie itself, the fact that Le Testu includes his title of Pilot de la mer $d u$ Ponent (Pilot of the Western Seas) in his signature enhances the manuscript's prospective character. In other words, his "gift" to Coligny is the theoretical and practical knowledge that the Norman pilot has gained from navigating the Western Seas, information that seems particularly relevant given the Admiral's interests in Terra Brasilis. In the context of European overseas expansion, the maps included in the Cosmographie, especially those dedicated to America, might have acted as a planning tool or even as an "elegant medium of propaganda," as Peter Barber has suggested when analyzing the multiple functionalities of early modern English map making. ${ }^{17}$ Given its possible uses or purposes, the fact that this is a manuscript atlas is not surprising. ${ }^{18}$ Norman cartography was intended for the French nobility and monarchy, and was generally offered as a sophisticated object that was only produced in small quantities upon request. ${ }^{19}$ The gift of one of these pieces, intended to visually reflect the crown's colonial aspirations and interests, was likely to yield some kind of compensation or reward. In exchange for the "gift-inprocess" that these maps (and the riches portrayed in their territories) represented, ship-owners could obtain a letter of marque and reprisal (Davies, 2016, p. 119). 


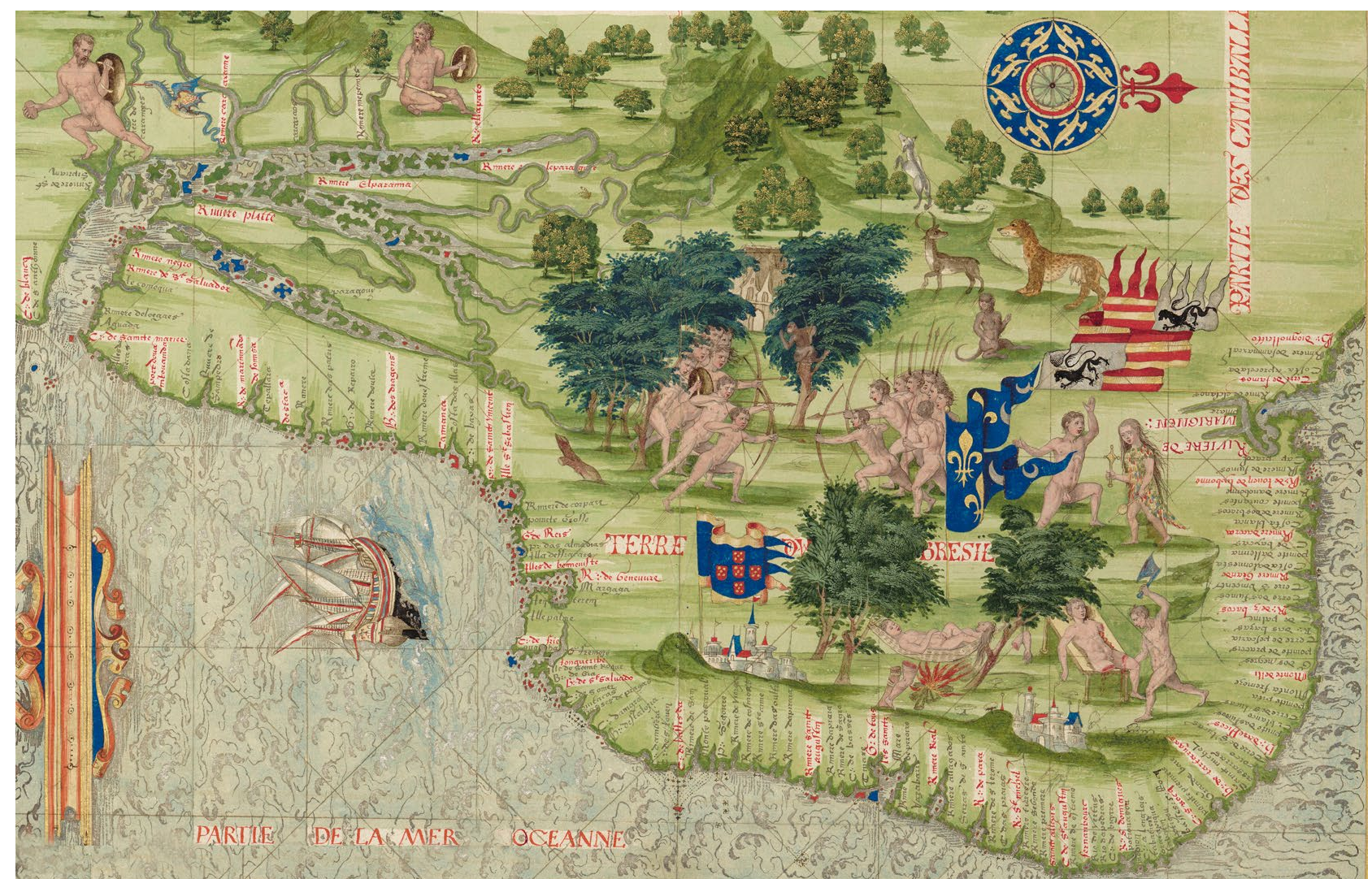

FIGURE 2. Guillaume Le Testu, Cosmographie Universelle. Selon les navigateurs tant anciens que modernes par Guillaume Le Testu pillotte en la mer du Ponent, de la ville françoyse de Grace, 1556. Detail of Folio XLIIII (sic.) verso. Bibliothèque Nationale de France - Service historique de la Défense (Cartes et atlas-portulans conservés dans les collections publiques françaises).

Analyses of the Cosmographie in relation to Portuguese cartography and French colonial claims are commonplace in scholarship on the Norman "school" of cartography (Anthiaume, 1911, 1916; Lestringant, 1991, 2012, 2013). ${ }^{20}$ The manuscript atlas' link with contemporary travel accounts, however, has received less critical attention. As mentioned above, a closer look at the New World motifs and texts included on the Cosmographie's fifteen maps of America reveals that the information Le Testu used to build an image of the New World may have come from his own incursions into American territory as well as from the Spanish and Portuguese chronicles and travel accounts published in the preceding decades. ${ }^{21}$ This coincides, in turn, with the relevance that Le Testu grants to certain areas of Pars Quarta in lieu of others. ${ }^{22}$ The Cosmographie devotes more than one map to Mexico, Peru, Brazil and the region now known as Patagonia. All of these areas had, in fact, been thoroughly described in America's founding narratives, which around the 1550s circulated across Europe in various formats and languages. ${ }^{23}$

In the absence of eyewitnesses whose testimony could support the Crown's colonizing interests, the images of America on Le Testu's fifteen maps were based on foreign experiences and accounts. In fact, with the exceptions of Brazil and Canada, French explorers had little or no firsthand experience of most of the American continent. Rath- er than solely reflecting the firsthand observations of Le Testu and other Norman navigators, the manuscript atlas synthesizes this information with the knowledge gained by those who had traveled under the command of rival powers. The act of making this information available to the French Crown could be considered a second form of translation, consisting not of the transposition of a text into a visual image, but of an experience produced in one context and interpreted in another. In this sense, the intellectual operations behind Le Testu's Cosmographie resemble the process described by Peter Burke when referring to intercultural translation. According to Burke, intercultural translation entails "a double process of decontextualization and recontextualization, first reaching out to appropriate something alien and then domesticating it" (Burke, 2007, p. 10). Accordingly, the Cosmographie turned the first Iberian incursions into American territory into a valuable source of knowledge, which was offered to France in the context of its colonial endeavors in America. This operation was not entirely new, though. Oronce Fine's 1531 and 1535 world maps had similarly drawn on the accounts of the Magellan-Elcano first voyage of circumnavigation and of Hernán Cortés' conquest of Mexico (Lestringant and Pelletier, 2007, p. 1467). After all, registering the latest discoveries overseas was one of the main concerns of Renaissance cartography (Du Verger, 2010, p. 44). 
Regarding the Cosmographie, how exactly Le Testu came across the information with which to elaborate his maps of America remains unknown. On the one hand, "it seems legitimate to infer that mapmakers were relying, at least partly, on oral and informal methods to gather information" (Davies, 2016, p. 134). Indeed, given that Norman ship-owners had financed Giovanni da Verazzano's voyages to Florida in 1524 and 1526, and Jacques Cartier and Jean-François de La Rocque de Roberval's expeditions to Canada in 1534 and 1542, it is probable that their findings circulated rapidly upon their return to France. On the other hand, in addition to the news that informally circulated in ports as well as between Norman ship-owners and cartographers, it is possible Le Testu had access to nautical manuals just as royal cosmographer André Thevet did (Lestringant and Pelletier, 2007, p. 1474). ${ }^{24}$ Likewise, the manuscript and printed versions of Cartier's and Roberval's voyages, among other documents, certainly influenced Le Testu's description of Canada in Folio LVIII. ${ }^{25}$ As Scott Juall has recently asserted, once he returned to France, Cartier handed François I written reports and a manuscript map of the coast of the St. Lawrence River, to which he also added an oral report (Juall, 2018, p. 349).

Undoubtedly, the importance of direct experience and cartographic tradition in the construction of a modern image of the world went hand in hand with the role played by the publishing market in the diffusion of images and information from the New World. ${ }^{26}$ In order to understand the enduring impact of America's founding narratives, the following section will delve into the links between text and cartographic image as encountered on the atlas' maps dedicated to the regions of Patagonia, Peru and Brazil. ${ }^{27}$ As will be demonstrated, all three cases evidence the impact of early modern travel experiences on Renaissance cartography. Carla Lois has suggested it was in this period that cartographic images condensed information on a "specific situation into a datable moment" (Lois, 2004, p. 11). Maps, in consequence, portrayed historical events, which were placed in specific locations and responded to specific contexts. Yet although Le Testu's Cosmographie was a by-product of the French attempts to expand overseas ${ }^{28}$ its images also capture multiple contemporary events resulting from the first decades of exploration and discovery. ${ }^{29}$ Much of this information was circulated in the accounts' original language of publication or in translation in France. One of the earliest editions of Columbus's letters in Latin, for instance, was published in Paris in 1493. In 1503, under the title of Alberic Vespuci laurentio Petri Francisci de Medicis Salutem plurimam dicit, the Latin translation of Americo Vespucci's first voyage to the New World was also published in Paris. The influence of these texts on the making of maps has also been verified in cases other than Le Testu's. Chet Van Duzer has recently proved that the 1505 letter of Vespucci to the Florentine chief of state Piero Soderini exerted a direct influence on the preparation of Pierre Desceliers's world map of 1550 (Van Duzer, 2015, p. 164)..$^{30}$ In his "Lettera," as the text came to be known, Vespucci narrates his four voyages to the New World under the command of the Iberian Crowns.

As for the availability of novel information about America in French, a compilation of Portuguese voyages from the early fifteenth century (the Itinerarium Portugallensium and Lusitania in Indiam, unde in Occidentem et demum ad Aquionem, published in Latin in Milan in 1508) was translated by Mathurin Du Redouer in 1515 and edited under the title of Le Nouveau Monde et lés navigations faictes par Emeric de Vespuce florentin. Des pays et isles nouvellement trouvez; Auparavant a nous inconneuz. Tant in l'Ethiopie que Arrabie, Calichut et aultres Plusiers regions estranges. Further, an extract of the famous Decades of Orbe Novo, by Pedro Mártir de Anglería (published in Seville in 1511), was translated into French and printed by Simon de Colines in Paris in $1532 .{ }^{31}$ As noted above, the influence of printed texts on the production of the Cosmographie is even more evident in the representation of areas not frequented by the French, such as Patagonia and Peru. Analysis of these cases sheds light on the extent to which cartographic images were based on published travel accounts.

\section{THE INFLUENCE OF PRINTED ACCOUNTS ON LE TESTU'S MAPS OF PATAGONIA}

Information about the Magellanic-Fuegian area and the South American Patagonian coasts available in Europe at the time of the Cosmographie came largely from the first circumnavigation of the globe led by Ferdinand Magellan and eventually completed by Juan Sebastián Elcano. Undertaken between 1519 and 1522, the expedition provided the founding narratives of South America's austral extremes, being the first to sail through what is now known as the Strait of Magellan at the juncture of the Atlantic and Pacific Oceans. Antonio Pigafetta's travel account, Francisco Albo's chronicle and Maximiliano Transylvanus' letter to Matthäus Lang von Wellenburg, the Cardinal-Archbishop of Salzburg, all described Magellan and Elcano's expedition in detail (Benites, 2014, pp. 82-83). By 1556, though, only Transylvanus' letter and Pigafetta's travel account had been translated and published in other languages. In the case of Transylvanus, his letter was first published in Cologne in 1523 under the title of De Moluccis Insulis. That same year, it was printed in book format by Pierre Viart in Paris and by Minitus Calvus in Rome. It was translated into Italian and reprinted in Venice in 1536 and, in 1550, included by Giovanni Battista Ramusio in the first volume of his Navigationi e Viaggi. Pigafetta's account was published by Simon de Colines in French in Paris in 1526. The protagonism of the Moluccas archipelago in narratives of the circumnavigation is evident both in Transylvanus's letter and Pigafetta's account, which was titled Le Voyage et navigation faict par les Espaignolz és Isles de Mollucques, des iles qu'ilz ont trouvé audict voyage, des roys d'icelles, de leur gouvernement et manière de vivre, avec plusieurs aultres choses...

Two further expeditions to the Strait were attempted between 1526 and 1534. Both failed but produced valu- 
able sources in the travel narratives of Captain Andrés de Urdaneta (who had been part of the expedition commanded by García Jofré de Loaysa in 1526), and the accounts of Alonso Veedor and Juan de Mori, two members of Simón de Alcazaba's 1534 expedition. ${ }^{32}$ All of these texts remained unpublished until the $19^{\text {th }}$ and early $20^{\text {th }}$ centuries. The final $16^{\text {th }}$ century Spanish incursions into the Strait region were undertaken by Pedro Sarmiento de Gamboa in 1579 and 1580. Gamboa recorded his experience of the area in four manuscript travel accounts, written between 1580 and 1590, more than two decades after Le Testu's Cosmographie was crafted..$^{33}$

Unlike the negative visions of the region portrayed in the texts of Gamboa, de Mori, and Veedor, Pigafetta's 1526 edition puts special emphasis on the positive features of the Magellanic-Fuegian area, an approach that Le Testu incorporates in his own description of Patagonia. In fact, the optimistic vision of Le Testu coincides in part with the lines that Pigafetta devotes to the Patagonian giants, as well as with the description of the birds of Brazil provided by the Italian navigator earlier in his account.

According to Le Testu, the Gigantum Regio (Region of Giants) is rich in "wild boar, deer and a sort of beast with the nose of a dog and big breasts. With many and diverse types of parrots and birds with their beaks like a spoon" ["sangliers, cerfs, biches et une sort de beste ayant le nectz cannis et grandes mamelles. Avec plusieurs et diverses sortes de papegaux et oeseaux ayant le bec faict ainsy comme une cuiller"] (Le Testu, 1556, Folio XLIIII recto). ${ }^{34}$ In his Voyage et navigation faict par les Espaignolz..., when describing Brazilian fauna, Pigafetta had previously stated: "there are infinite parrots and they give eight or ten for a mirror" ["il a infinis papegausx et en donne huyt ou dix pour ung mirouer"]. Remarkably enough, Pigafetta adds: "They have big birds whose beaks are like a spoon without a tongue" ["Ilz ont oiseaux grands ayans le bec comme une cuillier sans langue"]. Le Testu, like Pigafetta before him, compares the birds' beaks to a spoon. The influence of Pigafetta becomes evident again in the maps depicting the Kingdom of Ginganton. In Folio XLIII verso (Fig. 3), Le Testu includes the image of a beast which is similar to the description provided by Pigafetta of what might have been a guanaco. According to the Italian navigator: "The beast has a head and ears big as a mule, the neck and body like that of a camel and a tail like that of a horse as has rarely been seen on this land."

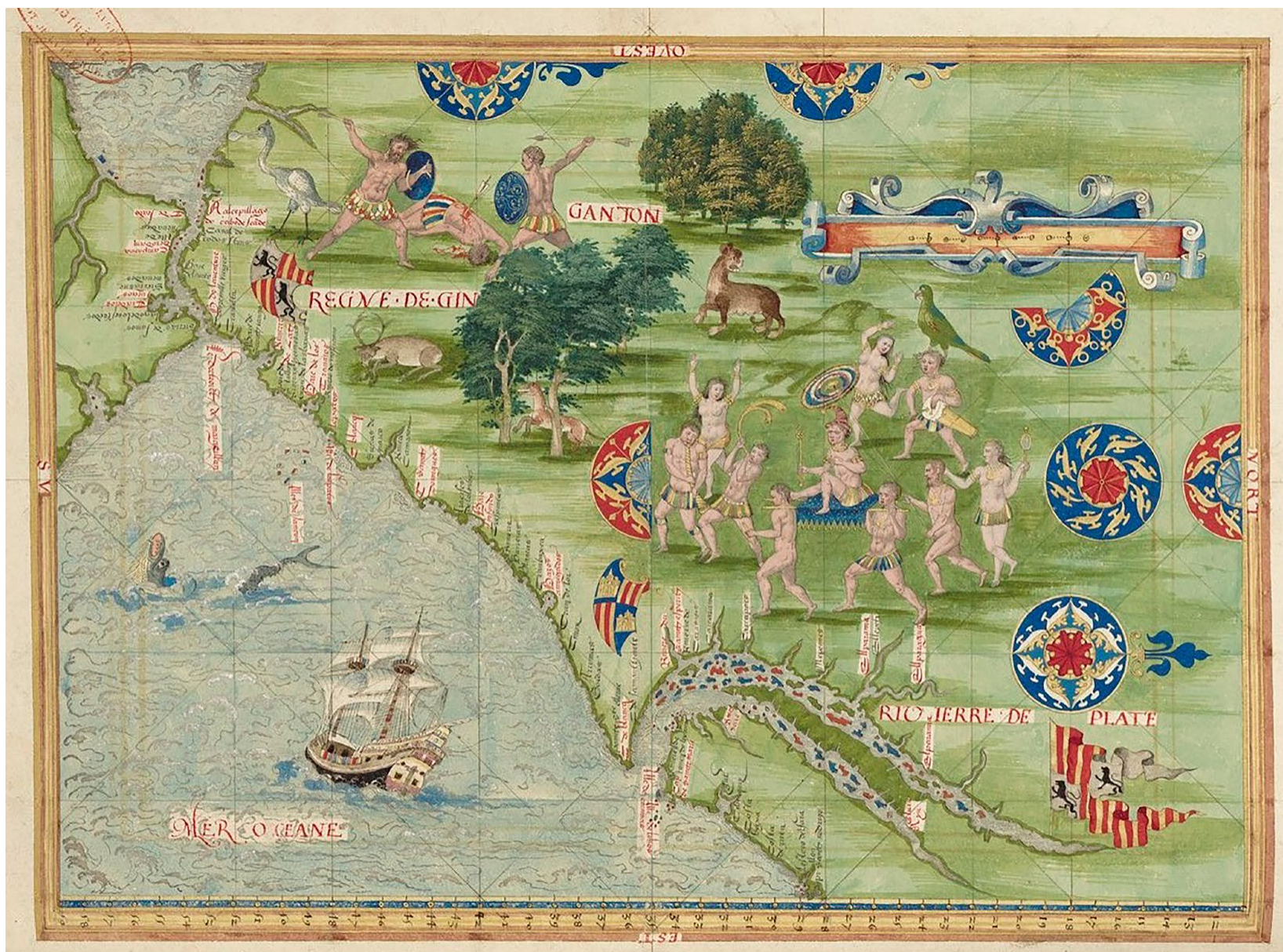

FIGURE 3. Guillaume Le Testu, Cosmographie Universelle. Selon les navigateurs tant anciens que modernes par Guillaume Le Testu pillotte en la mer du Ponent, de la ville françoyse de Grace, 1556. Folio XLIII verso. Bibliothèque Nationale de France - Service historique de la Défense (Cartes et atlas-portulans conservés dans les collections publiques françaises). 
["La beste a la teste et Les oreilles grande comme une mule et le col et le corps comme ung chameau et la queue comme ung cheval comme assez on veu en celle terre"].

Similarly, the region's toponym ("Royaume de Ginganton") as well as the description made by Le Testu of the size and food eaten by its inhabitants resembles that of Pigafetta. In Folio XLIX, the Norman pilot suggests: "The inhabitants of this region are big men who communicate by whistling: they only live on roots and some grains as they have no wheat, they also eat their animals raw" ["Les abitans de ceste Region sont grandz hommes lesquels s'entendent par sifler: seulement vivans de racines et de quelques grains sans avoir blectz, ansy mangent ilz leur bestial cru']. ${ }^{35}$ Further on, on Folio L, special emphasis is given to their great size and the region's resources:

The inhabitants here are ten to twelve elbows high, and only speak by whistling, just as Magellan witnesses, they live off certain grains such as maize, manioc and certain others: there are also animals such as tattoos, agouti and wolves, not as big as those in France, all of which they eat raw. This region produces parrots and different types of birds, of different kinds of colors and plumage (Le Testu, 1556: Folio L). ${ }^{36}$

The reference to Magellan in the excerpt above is an attempt by Le Testu to validate his assertions, which he claims are based on the information provided by the Portuguese captain. In fact, they were actually based on the account of another privileged eyewitness to the area: Antonio Pigafetta. The fact that Le Testu describes Patagonia as a land of parrots and manioc reveals, however, that the Norman pilot most probably combined a variety of unidentified sources, since Pigafetta does not associate these elements with the area. Le Testu's description of Patagonia also highlights therefore the fact that this region was still unexplored by France. Anyone navigating the coasts of South America's furthermost regions would have soon discovered its land and climate were unsuitable for both parrots and manioc. Regarding the influence of Pigafetta's account on this section of the Cosmographie, it is worth noting that the Italian navigator emphasizes the size of the Patagonians as well as their eating habits in his narrative. According to Pigafetta, the men were "so tall that we did not reach [their] waist" ["tant grand que ne luy benoient point à la ceinture"] (Pigafetta, 1526, Cap. VII, s/p). As regards the food they ate, the intake of roots and raw meat had previously been referred to by him as well: "The population dress with the skin of the afore mentioned beast and do not have a house but a hut made of the skins of this beast with which they go here and there, and live on raw meat and on a sweet root they call capar" ["Le peuple se vest de la peau de la beste devant dicte et n'ont point de maison sinon une cabane des peaux de la mesme beste avec laquelle vont ça et la et vent de chair crue et d'une racine douce qu'ils nomment capar"] (Pigafetta, 1526, s/p).

Remarkably, although Pigafetta is known for having originated the myth of the Patagonian giants, the first chronicler to write about giants in America was actually
Vespucci. Indeed, when describing his second voyage in his 1505 letter to Soderini, the Florentine refers to an "Island of Giants" (Vespucci, 1894, pp. 28-29). Although Vespucci was referring to a different region, a similar toponym was adopted by Le Testu to name both an island in the vicinity of Peru (i.e. the "Ille des Grands Hommes," in Folio XLIX verso) and a bay on one of his maps of Terra Australis (i.e. the "Baie des Grands Hommes," in Folio XL verso) (Fig. 4). The toponym is similarly illustrated by a giant man, who occupies most of this map and is representative of the "Kingdom of Ginganton." This giant offers an example of how "in addition to illustrating the toponym, the figure can also take the place of the toponym and become the emblem for that place" (Jacob, 2006, p. 167).

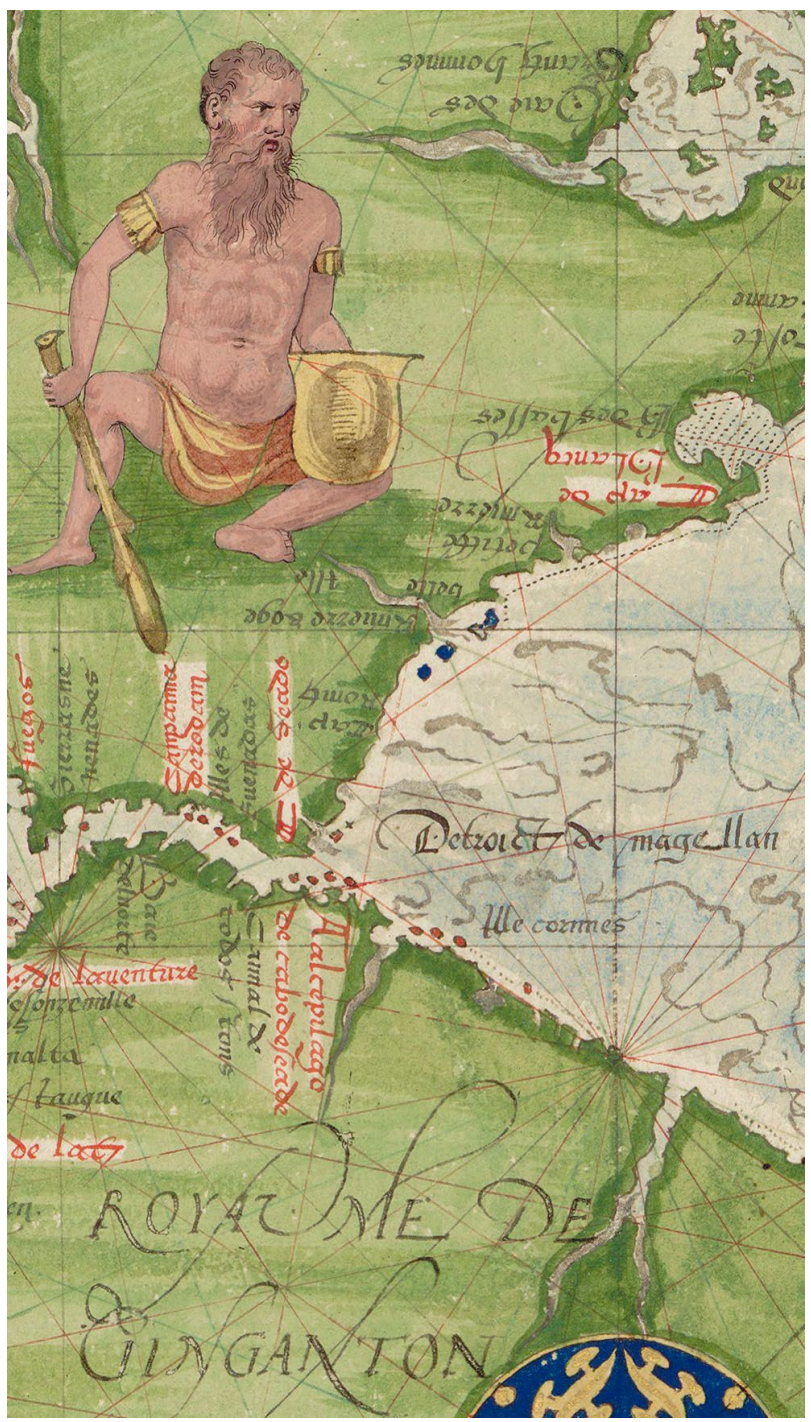

FIGURE 4. "Royaume de Ginganton." Guillaume Le Testu, Cosmographie Universelle. Selon les navigateurs tant anciens que modernes par Guillaume Le Testu pillotte en la mer du Ponent, de la ville françoyse de Grace, 1556. Detail of Folio XL verso. Bibliothèque Nationale de France - Service historique de la Défense (Cartes et atlas-portulans conservés dans les collections publiques françaises). 


\section{THE DEFEAT OF "ATABALIPA" IN PERU: SPAN- ISH CHRONICLES AU SERVICE DE LA FRANCE?}

By 1556, Spanish chroniclers had recorded the events of the conquest of Peru in various publications. In 1534, Francisco de Jeréz had published his Verdadera relación de la conquista del Perú, and more than a decade later in Seville, his Conquista del Peru: verdadera relacion de la conquista del Peru [et] provincia del Cuzco llamada la пиеи Castilla, conquistada por Francisco piçarro... (1547) was published. That same year, Gonzalo Fernández de Oviedo published his Coronica de las Indias: la hystoria general de las Indias agora nuevamente impressa corregida y emendada (1547). In the 1550s, Francisco López de Gómara wrote the Primera y segunda parte de la historia general de las Indias con todo su descubrimiento y cosas notables que han acaecido dende que se gano la Española y el Peru: con la conquista de Mexico y de la nueva España (1553) and La historia general de las Indias, con todos los descubrimientos y cosas notables que han acaecido enellas, dende se ganaron hasta agora (1554). A year before Le Testu's Cosmographie Universelle was completed, Agustín de Zárate published his Historia del descubrimiento y conquista del Peru: con las cosas naturales que señaladamente alli se hallan, y los sucesos que ha auido (1555), and Francisco López de Gómara added La historia general de las Indias y nuevo mundo con mas la conquista del Peru y de Mexico (1555) to his list of works. In this period, some of these texts were translated into Italian to circulate individually or as part of Giovanni Battista Ramusio's third volume of his 1556 Navigationi e viaggi. Similarly, between 1555 and 1576, six Italian editions of Pedro Cieza de León's Chrónica del Perú were published in Venice. Other works on the Spanish conquest of Peru were also translated from Spanish to Italian and later on into French. In 1545, for instance, the anonymous L'histoire de la Terre Neuue du Perù en l'Inde Occidentale, qui est la principale mine d'or du monde, nagueres descouuerte, \& conquise, \& nommeé la nouuelle Castille, was translated by Jacques Gohory and published by Jehan Barbier et Vincent Sertenas in Paris (Horodowich, 2005, p. 1042).

It is possible that information about Peru circulated in France thanks to this anonymous chronicle and to the map that was included in the French translation (1545). A close analysis of Folios L verso and LI recto of the Cosmographie sheds light on the impact this text might have had on the map titled "Partie de la defaicte d'Atabalipa au Peru," as well as on its accompanying text. In the latter, Le Testu explains:

The provinces and main cities are described as Pachachalmy, which is thought to be bigger than Paris, Chatames, the island of Colao. The Mosque of the Sun, which was the temple of the inhabitants of this land before Charles of Austria, the emperor of the Germans sent his ships to discover this land and, having discovered it, the Spanish conquered it. Pais Zaura, Capez, Cavaz, Gomachuco, Cuyo, Coasque, Bocraine, Archbishop of Venezuela: all of these cities and provinces were inhabited by savage people before the Spanish conquered them. This region is abundant in gold, silver and emeralds (Le Testu, 1556, Folio LI). ${ }^{37}$

Place names such as Gomachuco or Cusco, and Atahualpa himself, named "Atabalipa" in the 1545 translation as well as in Le Testu's Cosmographie, are spelled similarly in both cases. This, however, does not provide substantial evidence of the influence of the Histoire de la terre nеuиe du Perù on the Cosmographie. In fact, the Spanish chronicler speaks of the "Temple du soleil" while Le Testu opts for the term "Mosquée du soleil." The comparison of the temple with a mosque may well have come from other sources describing the conquest of Peru or from the map that accompanied the anonymous chronicle. ${ }^{38}$ For instance, in the same year the Cosmographie was dedicated to Coligny, Giovanni Battista Ramusio published the third volume of his Navigationi e Viaggi, which included an anonymous Relatione d'un capitano spagnolo della conquista del Peru and the Relatione de la conquista del Peru by Francisco de Jerez, secretary of Francisco Pizarro during the Andean expedition. Both chroniclers use the term "Mosque of the Sun" when referring to the Cuzco temples. ${ }^{39}$

Le Testu is unlikely to have had access to the work of Ramusio, published in Italian in Venice the same year he produced his Cosmographie. The fact that he is familiar with terms such as "Mosquée du Soleil" invites us, however, to reflect on his potential reading of similar sources. It is possible that the references to the abundance of gold and silver also came from the anonymous chronicle's translation. In fact, the defeat of Atabalipa, to which Le Testu devotes the map in Folio L verso (Fig. 5), is narrated in considerable detail at the end of Histoire de la Terre Neuve du Peru and is depicted on the map that was published with it. The battle between the Spanish and the inhabitants of Peru, as represented in that same Folio, also appears as a synthesis of the historical event. ${ }^{40}$ By 1556 , this was one of the only chronicles translated into French, although, as has been shown, the account was not the only printed text documenting Spanish actions in Peru.

As for the images included in Gonzalo Fernández de Oviedo's L'Histoire naturelle et générale des Indes (1555), they too may have influenced the Norman cartographer's representations of America. The engraving of a hammock (Fernández de Oviedo, Folio 72, recto) in Oviedo's work (Fig. 6), for example, might have inspired its inclusion on Le Testu's map of Brazil (Folio XLIIII sic). As Chet Van Duzer suggests, "knowledge and illustrations of the hammock were first diffused in Europe in Gonzalo Fernández de Oviedo's Sumario de la natural historia de las Indias" (Van Duzer, 2015, p. 176). Oviedo's influence, however, should be further assessed, as Le Testu could also have obtained information about this device from Vespucci and Pigafetta's travel accounts or from his own experience in Terra Brasilis. In fact, the engraving of a pineapple included by Oviedo to illustrate its characteristics and varieties (1555, Folio 110 verso) does not seem to have influenced Le Testu, who does not depict this fruit 


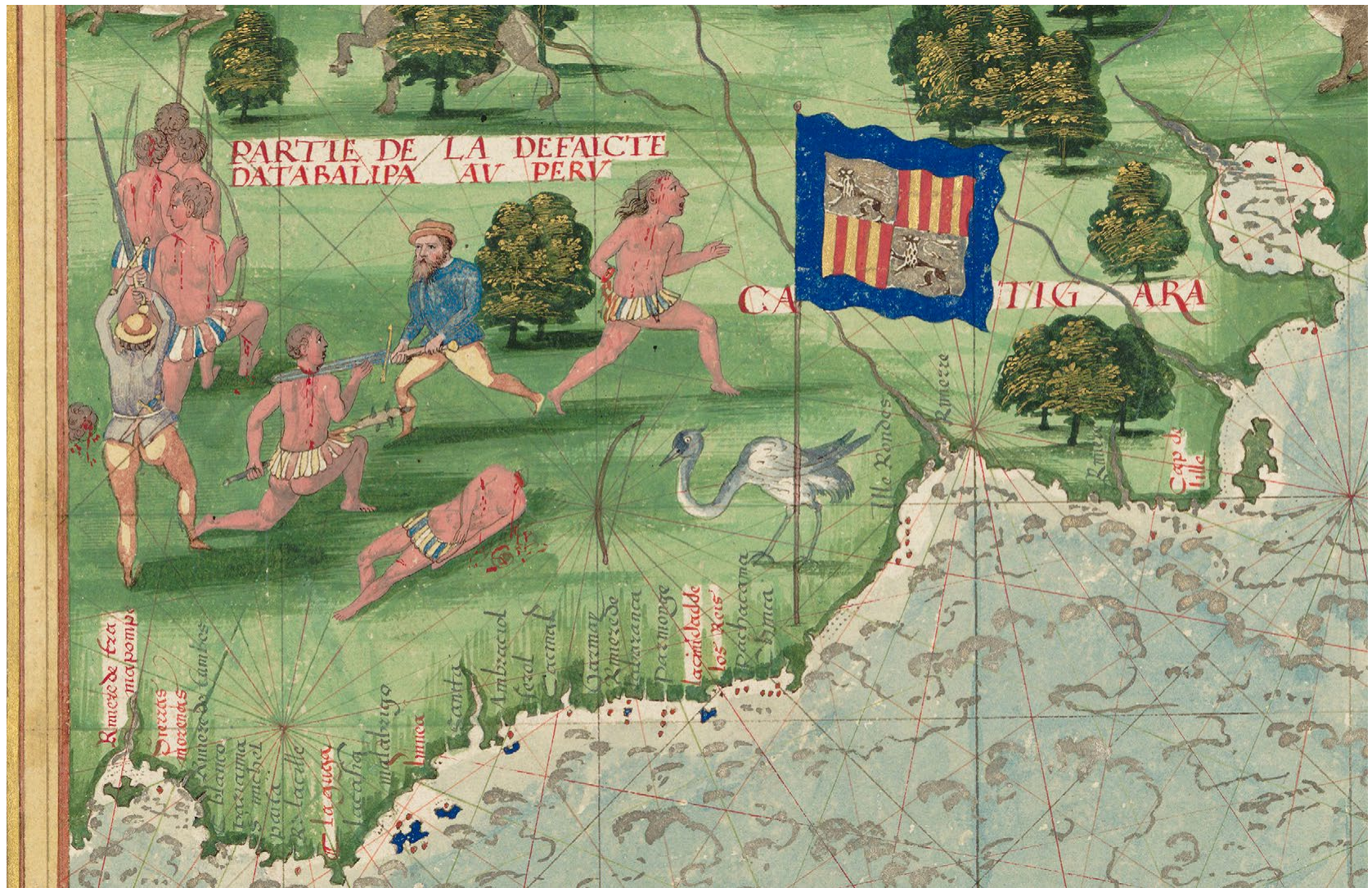

Figure 5. "Partie de la defacite de'Atabalipa au Peru." Guillaume Le Testu, Cosmographie Universelle. Selon les navigateurs tant anciens que modernes par Guillaume Le Testu pillotte en la mer du Ponent, de la ville françoyse de Grace, 1556. Detail of Folio L verso. Bibliothèque Nationale de France - Service historique de la Défense (Cartes et atlas-portulans conservés dans les collections publiques françaises).

at all on his maps of America. As has been shown above, the impact of Oviedo's works on the maps dedicated to the Kingdom of Peru is therefore not entirely evident. Undoubtedly, there is still more work to be done on the images of Peru included by Le Testu in his Cosmographie.

\section{TERRA BRASILIS IN LE TESTU'S COSMOG- RAPHIE: NUDITY, SAVAGERY AND AN- THROPOPHAGY}

As for the origin of the images on the maps of Terra Brasilis in the Cosmographie, according to royal cosmographer André Thevet, Le Testu had visited the region shortly before he produced the manuscript atlas. Apart from the information he most likely gathered in situ, there is evidence demonstrating the influence of Portuguese cartography and of previous works made by other Norman cartographers (such as Pierre Desceliers' 1550 world map) on Le Testu's representations of this region. ${ }^{41}$ Regarding the links between text and image in the specific case of Terra Brasilis, the influence of Vespucci and Pigafetta on both Portuguese and Norman cartography is undeniable.

A brief comparison of the "founding narratives" of New World encounters with the maps dedicated to Terra Brasilis in the Cosmographie demonstrates the lasting in- fluence of the descriptions of Italian explorers. Pigafetta, for instance, describes Brazilian (tupi) women in Chapter VI of his Le Voyage et navigation faict par les Espaignolz és Isles de Mollucques (1526) as follows: "She carries food in baskets in the mountains and other places, to be always with her husband, with an arc made of brazilwood or black palm, with a bundle of arrows made of cane. And they carry their children from their necks in a net made of cotton" ["Elle porte le menger en paniers sur les montaignes et austres lieux, pour estre toujours avecques son mary, avecques ung arc de bresil ou de palme noire, avec ung faisseau de fleches faictes de cane. Et portent leurs enfans attachez au col en une retz de coton"] (1526, s/p.). The presence of native women carrying baskets on their heads and their children wrapped in cotton cloths hanging from their necks while accompanying the men, in Folios XLV verso (Fig. 7) and XLVI verso (Fig. 8), might well be considered the translation into images of the behavior documented by Pigafetta.

It is once again the Vicenzan navigator who refers to the region's abundance, a feature that Le Testu highlights in his description of Brazil. As for the customs of its inhabitants, throughout chapter VI Pigafetta emphasises their nudity, their anthropophagical practices and the fact that they rest in thread-spun hammocks: 


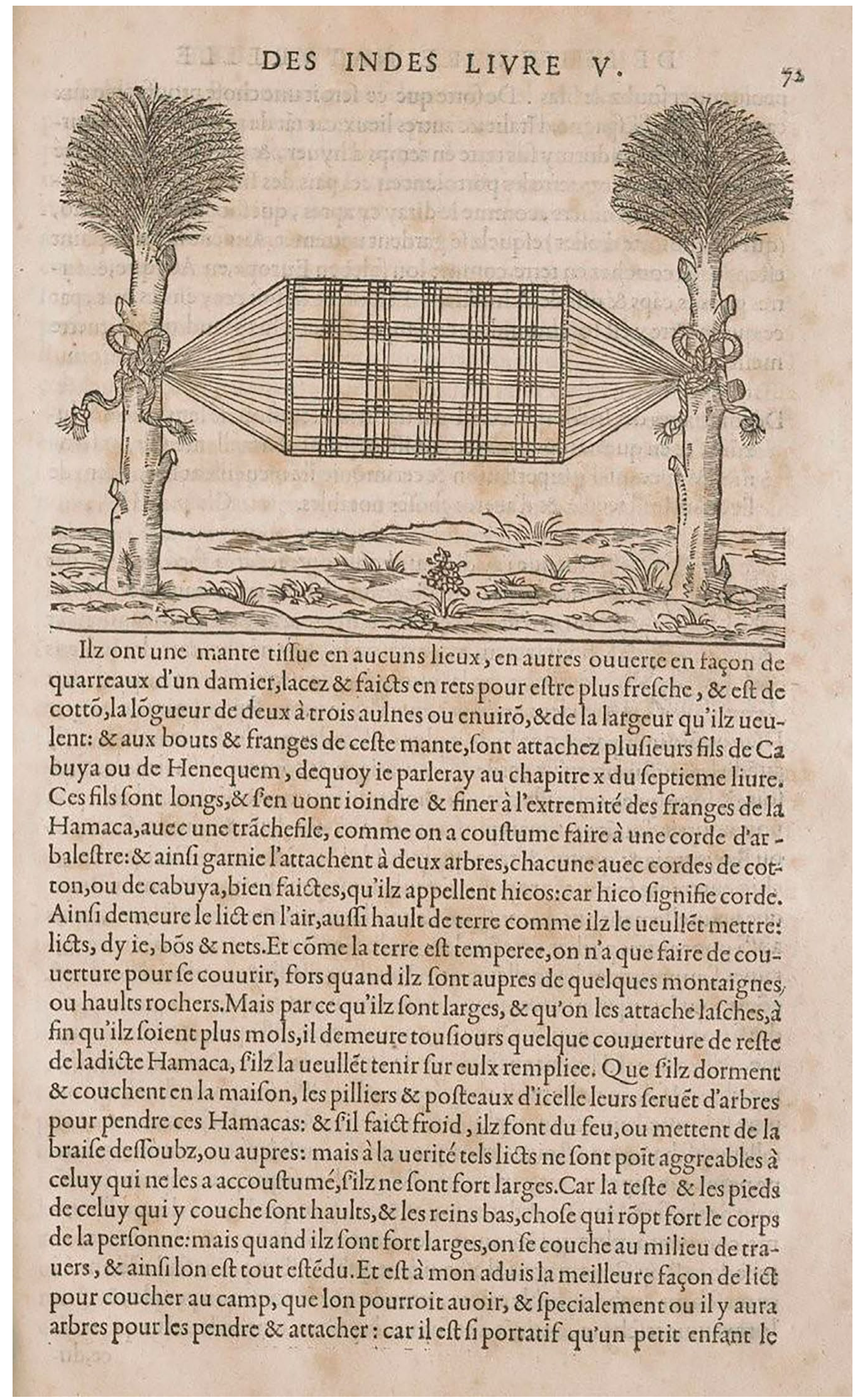

Figure 6. Gonzalo Fernández de Oviedo, Histoire naturelle et générale des Indes, Paris, 1555. Folio 72 recto. 


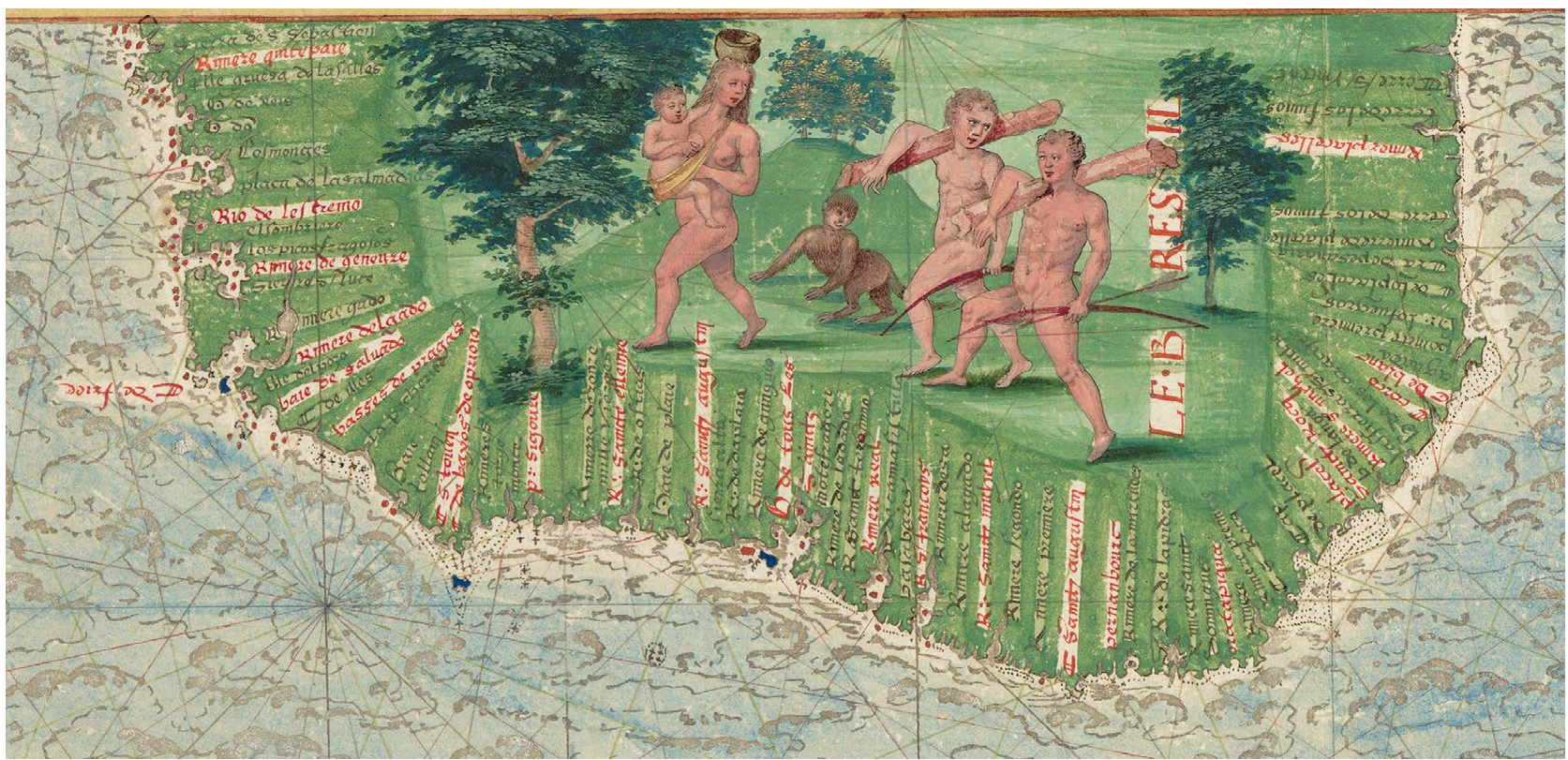

Figure 7. Terra Brasilis. Guillaume Le Testu, Cosmographie Universelle. Selon les navigateurs tant anciens que modernes par Guillaume Le Testu pillotte en la mer du Ponent, de la ville françoyse de Grace, 1556. Detail of Folio XLV verso. Bibliothèque Nationale de France - Service historique de la Défense (Cartes et atlas-portulans conservés dans les collections publiques françaises).

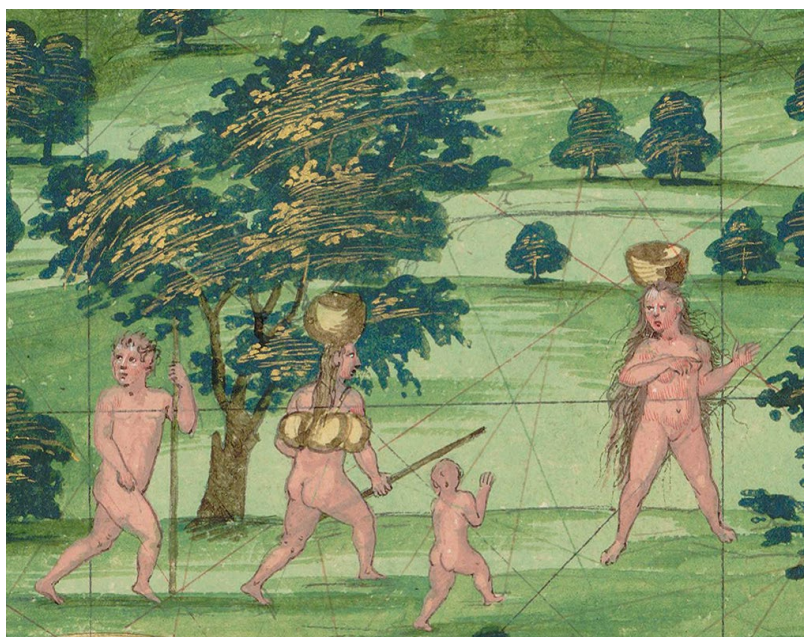

FIGURE 8. Terra Brasilis. Guillaume Le Testu, Cosmographie Universelle. Selon les navigateurs tant anciens que modernes par Guillaume Le Testu pillotte en la mer du Ponent, de la ville françoyse de Grace, 1556. Detail of Folio XLVI verso. Bibliothèque Nationale de France - Service historique de la Défense (Cartes et atlas-portulans conservés dans les collections publiques françaises).

Both men and women go around naked and live in long houses which they call boes and sleep in a net of cotton tied in the middle of their house from one side and the other to a thick piece of wood [...] The men and women are well disposed, as us. They eat human flesh from their enemies [...] They are neither black nor white but olive color. Their shameful parts are uncovered and are hairless in both men and women. [...] there are infinite parrots and they give eight or ten for a mirror (Pigafetta, 1526, s/p). ${ }^{42}$
The scenes of cannibalism and nakedness portrayed on Le Testu's maps seem to corroborate, once again, that the Norman pilot might have had access to some of the first reports on Brazil. Indeed, the descriptions that accompany these maps recall the images evoked by Vespucci in his letters to Soderini and Lorenzo di Pierfrancesco de Medici:

All of the inhabitants of this land are savages, as they have no knowledge of God. [...] All of the savages, those of the mountains as those of the coast, are naked, their lodgings and houses are covered with the bark of trees and leaves, they ordinarily fight against each other, those of the mountains against those of the coasts. This region is fertile in milcq (sic) and manioc, which is a white root with which they make flour to eat, as they make no bread (Le Testu, 1556, Folio XLV recto). ${ }^{43}$

Finally, the considerable quantity of information included in the "Brazilian section" of the Cosmographie must be understood in light of the establishment of the first French settlement in the area, founded by Vice Admiral of France Nicolas Durand de Villegagnon in the Bay of Guanabara (Rio de Janeiro) in $1555 .{ }^{44}$ The level of detail in this section further reflects the fact that Le Testu had supposedly explored the area in person. Given that by 1556 France's colonial ambitions lay firmly in Canada and in Brazil, the fact that the Cosmographie is addressed to Coligny is therefore unsurprising.

\section{FROM TEXT TO IMAGE: MODERN CARTOGRA- PHY AS A SYNTHESIS OF EXPERIENCE}

This analysis of American motifs in Le Testu's 1556 Cosmographie has focused on the process of translation 
in three different phases or dimensions. Firstly, that of translation in the strictest sense of the word, form one language to another. As has been shown, many of the chronicles and travel accounts published within the framework of Iberian transoceanic expansion were quickly translated into French so as to circulate them across the kingdom. Because of the information they included, these founding narratives were of vital importance to ship-owners, pilots and cartographers, who were keen readers of their rivals' exploits and failures. A second form of translation identified is that from text into image, which is evidenced in the strong correlation of the content of the travel accounts that were circulating around Europe at the time of the Cosmographie's production with its cartographic images. Finally, given the context in which the manuscript atlas was produced, the way in which previous Iberian encounters in America were capitalized upon by French colonial agents could be considered a third form of translation, whereby historical events were appropriated and cartographically synthesized in order to encourage French overseas expansion in the mid-sixteenth century.

As the Cosmographie shows, sixteenth century maps were intellectual objects that presented the observer with a synthetic image of a world in transformation (Davies, 2016 , p. 115). Whether handwritten or printed, Renaissance cartography condensed specific (historically datable) moments from the first period of the so-called "Age of Discovery." In their conjuring of an image of an ever-changing world, Le Testu's Cosmographie and the cosmographic genre in general were certainly not an exception. In fact, as Tom Conley has stated, it was in this period, and in France in particular, that "a new cartographic impulse" took place $(1996$, p. 2$) .{ }^{45}$ The process by which American motifs were standardized into specific topoi developed shortly after across diverse genres, such as costume books, atlases and iconologies.

One further aspect to highlight is that in addition to presenting a specific imago mundi in strictly geographical terms, Le Testu's manuscript atlas as well as the various early travel narratives and cartographic images of America were vital in the shaping of an American ethnographic subject. In this sense, the cartographic images and travel narratives of an as yet unexplored Pars Quarta played an important role in defining the American "other," whose habits and costumes (regardless of their accuracy) are displayed across the different regions of the fifteen in folio maps of America. The process of translating texts into images was not, however, free from contradictions. As Nicolás Kwiatkowski has pointed out, "transposition is capable of reversing some of the meanings of its productions, of recovering others, lost or hidden in the transposed work, and of introducing changes, distances, or new general keys for reading and observing" (2017, p. 48). In the case of the Cosmographie, the selection of certain scenes over others to illustrate historical processes (such as the underlying criticism of the Spanish conquest of the Inca empire in the "death of Atabalipa"), or to highlight the availability of specific resources, such as brazil-wood in Terra Brasilis, must be read in light of the interests of the
French Crown and its Norman ship-owners in a context of growing overseas competition.

The images of America in Le Testu's Cosmographie Universelle, then, contributed to the creation of a Pars Quarta endowed with a determined identity, constructed out of the careful selection of textual and visual elements present in its founding narratives. From the body of information available on America, Le Testu chose nudity, an exuberant fauna and flora, wealth (mineral and vegetable) and war as the region's most significant characteristics. ${ }^{46}$ Le Testu's characterization of America, however, is not exclusive to his cartography. The Cosmographie was one of many expressions in a long-term historical process via which an image of America was constructed. Despite the fact that the Cosmographie was handwritten and circulated only within the realm of the French monarchy, the actions and objects with which Le Testu represents American men and women circulated in areas beyond the Norman school of cartography and the realms of their Portuguese counterparts. In fact, the Cosmographie condenses a series of topoi exclusively associated with America about which information was circulating throughout Europe by the mid-sixteenth century. The presence of hammocks, monkeys, parrots, feathered costumes and abundant mineral wealth were but some of America's most noteworthy features whose origins can be located in the region's founding narratives.

\section{ACKNOWLEDGEMENTS}

I would like to thank Elizabeth Chant for her invaluable help and relevant comments when preparing this article. This article is one of the results of the research $\mathrm{R}+\mathrm{D}+\mathrm{i}$ Project CARTOPOLIC "Cartografías en movimiento. Circulación y construcción de los saberes geográficos en las monarquías policéntricas ibéricas" (UPO-1260972) funded by European Regional Development Fund (ERDF), Operational Programme 2014-2020 Junta de Andalucía. It is also a product of the ongoing project "Relatos de viaje, competencia ultramarina e imágenes cartográficas en la construcción de una imagen moderna del mundo (siglos XVI-XVII)," financed by the National Scientific and Technical Research Council (CONICET) of Argentina, and of a short-term research stay in Paris under the "Programme DEA (Directeurs d'Études Avancées)" of the Fondation Maison des Sciences de l'Homme (FMSH) in October 2020.

\section{NOTES}

1 Le Testu, G. (1556) Cosmographie universelle selon les navigateurs tant anciens que modernes, par Guillaume Le Testu, pillotte en la Mer du Ponent de la ville Francoyse de Grace. (1 atlas (118 p.): 57 col. ms. pl.; 55 x $40 \mathrm{~cm}$ ). Digitalized version available at: Paris: Bibliothèque Nationale de France: Collection numérique : Cartes marines sur parchemin (Cartes et atlas-portulans conservés dans les collections publiques françaises). The manuscript atlas is preserved at the Service historique de la Défense, D.1.Z14. Vincennes, France.

2 A detailed analysis of the Cosmographie's five continents can be found in Frank Lestringant's introduction to the first printed version of Le Testu's nautical atlas (2012, pp. 7-95). 
3 The debates over the geographical status of the New World in the sixteenth century and its growing definition as Pars Quarta in the decades following its European "discovery" have been analyzed in depth by Carla Lois (2008, pp. 263-264). As Lois suggests, the incorporation of America as a fourth part of the known world enabled geographers to integrate the newly discovered continent into a, so far, tripartite world (i.e. Europe, Asia and Africa).

4 This practice was not unusual. In the case of Pierre Desceliers' 1550 world map, the images and texts placed on the map owe much to Vespucci's travel accounts (Van Duzer, 2015, p. 164). The influence of Pigafetta is also discernable in the cartouche that indicates "Giants found by the Spanish" on the same map.

5 On the development of a new conscience of space and the gradual distance early modern geographers took regarding ancient representations of the orbis terrarum see Besse, J.-M. (2005).

6 In 1556, a French translation of Münster's cosmography was published by Henry Pierre under the title: La Cosmographie universelle, contenant la situation de toutes les parties du monde, avec leurs propriétéz et appartenances..

7 The relationship between text and image in the context of the engravings and illustrations of America produced in sixteenth century Europe has been analyzed in detail by Joan Pau Rubiés (2008, pp. 236-237)

8 Although Davies admits that Pierre Desceliers' world map incorporated much of the information provided by Vespucci's accounts, she nevertheless clarifies that "the numerous editions and translations of letters attributed to Vespucci had little impact on Norman iconography" (2016, p. 128).

9 The relationship between text and image in the early modern period has been analyzed with more or less emphasis in numerous works over the last decades. From Claire Farago's broad spectrum analysis on Renaissance visual culture and the cultural exchanges of European and non-European peoples in Reframing the Renaissance. Visual Culture in Europe and Latin America 1450-1650 (1995) to more specific works such as Michael Gaudio's Engraving the Savage. The New World and Techniques of Civilization (2008), Michiel van Groesen's approach to the influence of travel narratives in the depiction of New World inhabitants in the De Bry collection of voyages (2008) or Benjamin Schmidtt's (2001) analysis of the influence of New World images on the shaping of Dutch identity once the United Provinces became independent from the Spanish Crown.

10 Homem, L. (1519) Atlas nautique du Monde, dit atlas Miller. Illuminated manuscript, 42 x $59 \mathrm{~cm}$. At: Paris: Bibliothèque Nationale de France, Département Cartes et plans, GE DD-683 (5 RES).

11 Gaspard de Coligny was the Admiral of France between 1552 and 1572, when he was killed during the Saint Bartholomew's Day Massacre.

12 Scott Juall instead refers to the "Dieppe School of Hydrography" as a key element in the construction of France's imperial gaze (2018, p. 353). Whether it was actually a school or not has been debated by Frank Lestringant, who referred to the cartographers and their productions as part of a Norman "atelier" (2012).

13 As Axelle Chassagnette has pointed out, throughout the 16th century the circulation in Europe of Portuguese and Spanish cartographers, as well as of their works, became a practice that was welcomed by the rivals of the Iberian crowns $(2018$, p. 8).

14 The presence of Portuguese mapmakers and navigators in the French ports along the English Channel has been analyzed by Sarah Toulouse, who claims "pilots of Portuguese ships had been working in France since the beginning of the sixteenth century." Aside from mentioning the arrival of Portuguese cartographer, João Afonso, to the French court, Toulouse also considers that "these Portuguese cartographers may well have worked in Normandy, passing on their knowledge, cartographic style, place-names, and coastal outlines to their Norman counterparts" (Toulouse, 2007, p. 1555). More information on this subject can be found in Luís de Matos (1952, pp. 15-18).

15 The Norman "school" of cartography paid special attention to Java Major, which was depicted as the promontory of a suppos- edly existent Pars Quinta or Terra Australis nondum cognita (Sottas, 1912, p. 69).

16 Alfredo Pinheiro Marques (1994) has asserted the Miller atlas was the joint work of the young noble Lopo Homem and the Reinel family, the oldest dynasty of cartographers in Portugal. According to Pinheiro, the maps were illuminated by António de Holanda. An in-depth analysis of the Miller atlas can be found in Thomas, Marques and Nogueira (2006). Regarding the influence of Portuguese portulan maps in the cartography of the Norman city-ports, the work of Sarah Toulouse is of particular relevance. However, the similarities between $16^{\text {th }}$ century Portuguese cartography and Guillaume Le Testu's Cosmographie Universelle need to be explored further. See Toulouse (2001).

17 In the case of England, Peter Barber resorts to the observations of the former secretary of the Privy Council, Sir Thomas Elyot, to examine the character of maps: "In addition to their utility for generals who need to visualize the camp of their enemy [...], he wrote that maps could be adapted 'to the adminiculation [support] of other serious studies and business.' They could be used as a planning tool [...], and as a means of persuasion [...]. This emphasis on the map's role as an elegant form of propaganda as well as its planning function was significant, as many of the earliest surviving utilitarian maps created for use at court combine both roles - the rough, preliminary sketches having in most cases been lost" (Barber, 2007: 1598). The prospective character of early modern maps has also been emphasized by Frank Lestringant and Monique Pelletier in the following question: "Was not the very act of drawing up a map intended as an experiment with physical space that could mold the future by giving orientation to the present?" (2007, p. 1463).

18 According to Chet Van Duzer, "the whole output of Norman cartography was manuscript, not printed, which limited its diffusion and thus its influence. The Norman mapmakers were content to make elaborate, expensive hand-painted maps for nobles, rather than seek a wider audience through printed maps" (2015, p. 73).

19 This did not mean the purpose of such works was only decorative. $C f$. Sarah Toulouse (2007, p. 1561).

20 One of the first works on Le Testu was by Albert Anthiaume (1911). On the importance of Norman cartography see Albert Anthiaume (1916).

21 Le Testu's voyage to Terra Brasilis is mentioned in a posthumous work by royal cosmographer André Thevet. In Histoire d'André Thevet Angoumoisin, Cosmographe du Roy, de deux voyages par luy fait aux Indes australes, et occidentales, currently held in the French manuscript section of the Bibliothèque Nationale de France (code 15454, fo. 135v.), Thevet claims Le Testu sailed with him to Brazil between 1551 and 1552 .

22 "The fifty regional maps, despite their number, do not offer complete coverage of the world, omitting parts of South America, the South Atlantic, central Africa, and the southern continent - and much of the hinterland of Asia" (Van Duzer, 2015, p. 25).

23 Coincidentally, because of their commercial value all of these regions were of interest to the late-coming maritime powers. According to Sarah Toulouse, "the features illustrated within the land masses and the commentaries that accompany the charts are often economic in character, describing the various products to be found in a particular region. [...] Indeed, the very choice of the regions to map was linked to the existing circuits of trade" (2007, p. 1562).

24 Some of the nautical manuals collected by Thevet included Manuel Álvares' Roterio de navegaçam daqui pera y India; Pierre Garcie (Ferrande)'s Le grand routtier, pillotage et encrage de mer; two copies of Jean Alfonse de Saintonge's Voyages avantureux; Olivier Bisselin's Tables de la declinaison ou esloignement que fait le soleil de la ligne equinocitale; and Michel Coignet's Instruction nouvelle des poincts plus excellents et necessaires touchant l'art de naviguer.

25 The habits of the "sauvages" in Canada are described in Folios LVI verso, LVII recto and verso, and Folio XVIII recto of Le Testu's Cosmographie Universelle. In Folio LVIII, Le Testu mentions Cartier and Roberval's recent voyages: "Ceste est une partie ou portion de la Terre Neufue, dict Region de bacaillaux, 
marquée ensuivant les anciens navigateurs. Lesquels n'ont parlé des comodites d'icelle jusque a ce que Robert Val \& Jacques Cartier y ayent esté, par le commandement du Roy Francoys Premyer de ce nom, lesquelz ont decouvert le Canada \& saguene, comme vous avez peu voir a la page precedente.” In 1545, A. Leclerc had published Cartier's Brief recit de la navigation faicte es ysles de Canada... in Paris.

26 María Jesús Benites has suggested that voyages were the first ways of appropriating the New World. Writing chronicles and travel accounts about those lands verbalized the possession of space implied in the first explorations of Pars Quarta (2014, pp. 80-81).

27 The selected maps are: 1) the "Kingdom of Ginganton" in the southern borders of South America in Folios XLIII and XLIX; 2) the Kingdom of Peru in Folio L verso; and 3) the description of the Rio de la Plata and Terra Brasilis, presented jointly in Folios XLIII verso and XLV recto.

28 In the texts accompanying each of these maps, Le Testu describes the riches of each region and their commercial value. According to Sarah Toulouse: "At the time, the primary aim of oceanic voyages and attempts at colonization was commercial development, which is reflected in the charts themselves. The features illustrating the land masses and the commentaries that accompany the charts are often economic in character, describing the various products to be found in a particular region" (2007, p. 1562).

29 America is not, however, the only region represented in the Cosmographie upon which historical characters are mentioned or drawn. On the maps of Asia and Africa, legendary characters such as the Great Kan and Prester John; the crossing of the Red Sea, and the destruction of the Pharaoh or of Sodoma are also present (Sottas, 1912, p. 70).

30 According to Van Duzer, "in all probability Desceliers translated this material into French from the Latin edition of Vespucci's letter in the Novus orbis" (2015, p. 264).

31 Its title was Extrait ou recueil des isles nouvellement trouvées en la Grand mer Oceane au temps du roi d'Espaigne Ferdinand et Elisabeth sa femme, faict premierement in latin par Pierre Martyre de Milan et depuis translate en langaige francoys (Chinard, 1911, p. 16).

32 The accounts of Veedor and Mori were first published in 1935 by Pablo Pastells in El descubrimiento del Estrecho de Magallanes. En conmemoración del IV centenario, under the titles of Relación de lo que sucedió en la expedición y Armada de Simón de Alcazaba al Estrecho de Magallanes hasta su vuelta a la isla de Santo Domingo and Relación escrita por Juan de Mori de lo ocurrido en la expedición de Simón de Alcazaba al Estrecho de Magallanes, desde que salió de Sanlúcar de Barrameda hasta que llegó a Santo Domingo, respectively (Benites 2015, p. 84).

33 Gamboa's travel accounts were Relación y derrotero (1580), Relación de lo sucedido a la Armada Real de Su Majestad en este viaje del Estrecho de Magallanes (1583), Relación hecha por Pedro Sarmiento a Su Majestad sobre lo sucedido en el Estrecho (1584) and the Sumaria Relación of 1590 (Benites, 2014, p. 85). Gamboa's descriptions of the area most certainly surpass the images represented by Le Testu in his Cosmographie. However, it is interesting to mention the extent to which Gamboa endorses the despairing vision of the region expressed in the texts of Veedor and Mori. At least for Spain, Gamboa's was the last attempt to find wealth in the region. "En todo este estrecho desde la mar del norte hasta llegar a la cordillera que son quarenta y tres leguas el estrecho adentro, no hay marisco, ni chocos, ni lapas, hierbas de las de la mar de las que comer, ni pescado se puede tomar en invierno," writes Sarmiento de Gamboa about the region (quoted in Benites 2014, pp. 84-85). Unlike Gamboa, de Mori and Veedor, there are no hints of despair in Pigafetta's text.

34 All of the translations in the present article have been done by the author. The spelling and grammar of the texts in sixteenth century French have not been altered.

35 In Folio XLIX, Le Testu describes the Kingdom of Ginganton as follows: "This land is part of America, of the Kingdom of the giant, also referred to as Ginganton, it borders the Strait of Magellan in the south, the South Sea in the West, it is placed in the temperate zone, under the first climate 'antidia meroes', and extends up to the ninth climate 'antidiadamias'. The inhabitants of this region are men of great size who communicate by whistling..." ["Cest terre est une partie de Amerique, du ceste du Royaume de gingant ou austrement dict ginganton, envyronne du cest due midi du detroit de magellan, du ceste doccident la mer du su, située soubz la zonne temperée, soubz le milleu du premier clima antidia meroes, et finissant soubz la fur du neufiesme climat antidiadamias. Les abitans de ceste Region sont grandz hommes lesquels sentendent par sifler"].

36 "Les abitants dicelle sont grandz de dix a douze couldes de haulteur, \& ne parlent poinct que par sifler, ainsy comme tesmoigne Magellan, ils vivent de quelques grains comme milcq, manioc, $\&$ quelques autres sortes : ansy y a il bestial comme tatons, agoutins, \& loups, non sy grandz comme ceux du pays de France, toutes lesquelles chers ilz mengent crues. Ceste region rourit papegaulx et plusieurs sortes de oiseaulx de diverses coulleurs de plumage."

37 "Les provinces et principalles villes sont decriptes comme pachachalmy, ville estimée plus grande que Paris, Chatames, l'ille de Colao. La mosquée du soleil, qui estoit le temple des abitans de ceste terre, auparavant que Charles d'autriche empereur des germains eut envoyé de ses navires pour faire decouverture et ayant faict cest decouverture les espaignolz l'ont conquize. Pais Zaura, Capez, Cavaz, Gomachuco, Guyo, Coasque, Bocraine, archeueche de Venensuelle: toutes lesquelles villes et provinces estoient abités de personnes saulvages auparavant que les dictz espaignolz l'eusent conquize. Ceste region est abondante en or et en argent et emeraudes."

38 The possible influence of the map made by Nicolas Denisot (Conte d'Ansinoys), inserted in the French version of the 1545 Spanish chronicle, on Le Testu's cosmography is being further studied. In fact, the influence of Denisot's map (i.e. its place names and the spatial distribution of the main political centers depicted) on Le Testu's map of Peru is the object of an ongoing research project. As to Denisot's map itself, the most relevant works on its origin and its inclusion in the French translation of the Spanish chronicle on the Peru are: Marcel (1894); Bowen (1938) and Speziari (2016).

39 See Folio 313 verso of the Relatione d'un capitano spagnolo della conquista del Peru and Folio 326 verso of Jerez's Relatione de la conquista del Peru, por Francisco de Jerez in Giovanni Battista Ramusio (1606).

40 In fact, this is one of the few maps in the Cosmographie upon which the Spanish are represented.

41 As this article has argued, the Atlas Miller (1519) may well be an example of its influence.

42 "Tant hommes que femmes vont nudz et habitent en longues maisons lesquelles appellent boes et dorment en une retz de coton liée au milieu de la maison d'ung bout a l'autre a gros bois [...] Ils sont hommes et femmes disposez comme nous. Ils mangent chair humaine de leurs ennemis [...] De leur nature ilz ne sont ne noirs ne blancz mais de couleur d'olive. Ils portent la partie vergogneuse descouverte sans aucun poil tant hommes que femmes. [...] il a infinis papegaux et en donne huyt ou dix pour ung mirouer."

43 "Tous les abitans de ceste Terre sont sauvages, nayant cognoiscance de dieu. [...] Tous les dictz sauvages tant de lamont que de laval sont nutz, ayans leurs loges et maisons couvertes de corche de boys et de feuilles, ilz mennet ordinairement guerre les uns contre les austres, cest a savoir ceux des montaignes contre ceux du bord de la mer. Ceste region est fertille en milcq et manioc, qui est une racine blache de qoui ilz font de la farine pour menger, car ilz ne font poinct de pain..."

44 The colony was attacked and destroyed by Portuguese troops under de command of Mem de Sa in 1560.

45 According to Conley, cartographic reasoning inspired both the graphic and the imaginary forms of literature in Renaissance France. The works of Descartes, Montaigne and Rabelais, says Conley, were expressions of this new spatial form of cartographic writing, textual organization and visual representation. Regarding the cartographic production of the so-called Dieppe school, 
the fact that a year after Le Testu signed his Cosmographie, royal cosmographer André Thevet published his Singularitez de la France Antarctique in Paris should be interpreted as a product of that same impulse or context. One must not forget, however, that the production of geographical works in the context of European overseas competition was also the result of specific political and even religious objectives or intentions.

46 According to Chet Van Duzer "some elements typical of European representations of South America during this period [were]: hammocks, parrots, native peoples with feather skirts, and a monkey; and the scene of mining in the west alludes to the continent's mineral wealth" (2015, p. 122).

\section{REFERENCES}

Anon. (1545) L'histoire de la terre neuve du Perù en l'Inde Occidentale, qui est la principale mine d'or du monde, nagueres descouverte, \& conquise \& nommé la nouvelle Castille, Traduitte d'Italien en Francoys. Paris: Vincet Sertenas.

Anthiaume, A. (1911) "Un pilote et cartographe havrais au XVI siècle, Guillaume Le Testu.” Bulletin de Géographie historique et descriptive, 1-2, pp. 11-21.

Anthiaume, A. (1916) Cartes marines, constructions navales, voyages de découvertes chez les Normands, 1500-1650, préface de l'amiral Buchard. Paris: Imprimerie Nationale.

Barber, P. (2007) "Mapmaking in England, ca. 1470-1650." In: D. Woodward, ed., The History of Cartography, vol. 3, Cartography in the European Renaissance (Part 2). Chicago: The University of Chicago Press, pp. 1589-1669.

Benites, M. J. (2014) “'Vigilias, fatigas y peregrinaciones': viaje, relato y desamparo en los confines del imperio." Telar, 11-12, pp. 80-97.

Besse, J. M. (2003a) Les grandeurs de la Terre. Aspects du savoir géographique à la Renaissance. Paris: Éditions de l'ENS.

Besse, J. M. (2003b) Face au monde. Atlas, jardins, géoramas. Paris: Desclée de Brouwer.

Besse, J. M. (2005) "La géographie de la Renaissance et la représentation de l'universalité." Memorie Geografiche. Supplemento alla Rivista geografica italiana, Socità di Studi Geografici, 5, pp. 147-162.

Bowen, W. H. (1938) 'L'Histoire de la terre neuve du Perù, a translation, by Jacques Gohory." ISIS (Quarterly Organ of the History of Science Society and the International Academy of the History of Science), 77 (XXVIII, 2), pp. 330-340. doi: https:// doi.org/10.1086/347334

Burke, P. (2007) "Cultures of translation in early modern Europe," in P. Burke and R. Po-Chia Hsia, Cultural Translation in Early Modern Europe. Cambridge: Cambridge University Press, pp. 7-38.

Chassagnette, A. (2018) "La géographie au service des princes: cartes, inventaires et descriptions des territoires, $\mathrm{XVI}^{\mathrm{e}}-\mathrm{XVII}$ siècle." In: P. Boucheron, M. Folin and J.-P. Genet, dirs., Entre idéel et matériel: Espace, territoire et légitimation du pouvoir (v.1200-v.1640) [en ligne]. Paris: Éditions de la Sorbonne. Available at : http://books.openedition.org/psorbonne/41093. Accessed: 23 Nov. 2020.

Chinard, G. (1911) L'exotisme américain dans la littérature française au XVIe siècle. Paris: Hachette.

Conley, T. (1996) The Self-Made Map. Cartographic Writing in Early Modern France. Minneapolis-London: University of Minnesota Press.

Davies, S. (2016) Renaissance Ethnography and the Invention of the Human. New Worlds, Maps and Monsters. Cambridge: Cambridge University Press.

Du Verger, J. (2010) "Géographie et cartographie fictionnelles dans l'Utopie (1516) de Thomas More." Moreana, 47 (181-182), pp. 9-68. doi: https://doi.org/10.3366/more.2010.47.3-4.3

Farago, C. J., ed. (1995) Reframing the Renaissance. Visual Culture in Europe and Latin America 1450-1650. New Haven and London: Yale University Press.
Fernández de Oviedo, G. (1555) L'histoire naturelle et generalle des Indes, isles et terre ferme de la grand mer Oceane. Traduicte de castillan en françois. Paris: De l'imprimerie de Michel de Vascosan.

Gandini, M. J., López Palmero, M., Paredes, R. C., and Martínez, C. (2013) Fragmentos imperiales. Textos e imágenes de los imperios coloniales en América (siglos XVI-XVIII). Buenos Aires: Editorial Biblos.

Hanks, W. F. and Severi, C., eds. (2015) Translating Worlds. The Epistemological Space of Translation. Chicago: Hau.

Hartog, F. (1988) The Mirror of Herodotus. The Representation of the Other in the Writing of History, translated by Janet Lloyd. Berkeley: University of California Press.

Horodowich, L. (2005) "Armchair Travelers and the Venetian Discovery of the New World." The Sixteenth Century Journal, 36 (4), pp. 1039-1062.

Jacob, Ch. (2006) The Sovereign Map. Theoretical Approaches in Cartography throughout History. Chicago and London: The University of Chicago Press.

Juall, S. D. (2018) “France's Mid-Sixteenth-Century Imperial Gaze on Canada: The Dieppe School of Hydrography, the Kingdom of Saguenay, and the Mise en scène of Possession.” In: J. Persels, K. Tarte, and G. Hoffmann, eds., Itineraries in French Renaissance Literature. Essays for Mary B. McKinley. Leiden-Boston: Brill, pp. 349-376.

Kwiatkowski, N. (2017) "Palabra e imagen en la modernidad temprana. Representaciones de la barbarie mediante ilustración, écfrasis y alegoría.” Boletín de Estética, 39 (13), pp. 43-94.

Lestringant, F. (1991) "Le déclin d'un savoir. La crise de la cosmographie à la fin de la Renaissance." Annales. Économies, Sociétés, Civilisations, 46 (2), pp. 239-260. doi: https://doi. org/10.3406/ahess.1991.278945

Lestringant, F. (2012) "Peindre le monde. Guillaume Le Testu, navigateur et cartographe de la Renaissance.” In: G. Le Testu, Cosmographie Universelle selon les navigateurs tant anciens que modernes. Paris: Arthaud, pp. 7-95.

Lestringant, F. (2013) "La Cosmographie Universelle de Guillaume Le Testu (1556). Au croisement de la géographie savante et de la science nautique des portulans." Revue du CFC, 216, pp. 91107.

Lestringant, F., and Pelletier, M. (2007) "Maps and Descriptions of the World in Sixteenth-Century France.” In: D. Woodward, ed., The History of Cartography, Vol. 3, Part 2: Cartography in the European Renaissance. Chicago: The University of Chicago Press, pp. 1463-1479.

Lois, C. (2004) "Cartografías de un Mundo Nuevo." Terra Brasilis, 6. doi: https://doi.org/10.4000/terrabrasilis.363

Lois, C. (2008) "América quarta pars: ¿isla o continente? El debate conceptual sobre el estatus geográfico del Nuevo Mundo en el siglo XVI." Fronteras de la Historia, 2 (12), pp. 259-279. doi: https://doi.org/10.22380/20274688.493

Marcel, G. (1894) “Le Conte d'Alsinoys géographe.” Revue de Géographie, 9, pp. 1-7.

Marques, A. P. (1994) "L'atlas Miller: un problème résolu. L'art dans la cartographie portugaise." Revue de la Bibliothèque National de France, 4, pp. 53-57.

Martínez, C. (2019) "'Salvajes desnudos, feroces y caníbales': textos fundacionales e imágenes cartográficas en la construcción de América como Pars Quarta.” In: S. Tieffemberg, comp., Pensar América desde sus colonias. Textos e imágenes de América colonial. Buenos Aires: Biblos, pp. 37-58.

Matos, L. de (1592) Les Portugais en France au XVIe siècle, Études et documents. Coimbra: Acta Universitatis Conimbrigensis.

Pagden, A. (1997) Señores de todo el mundo. Ideologías del imperio en España, Inglaterra y Francia (en los siglos XVI, XVII y XVIII). Barcelona: Editorial Península.

Pigafetta, A. (1526) Le voyage et navigation faict par les Espaignolz és Isles de Mollucques, des iles qu'ilz ont trouvé audict voyage, des roys d'icelles, de leur gouvernement et manière de vivre, avec plusieurs autres choses. Paris: Simon de Colines. 
Ramusio, G. B. (1606) Delle Navigationi et Viaggi, Volume Terzo. Venice: I Giunti.

Rubiés, J. P. (2008) "Imagen mental e imagen artística en la representación de los pueblos no europeos. Salvajes y civilizados, 1500-1650.” In: J. L. Palos and D. Carrió-Invernizzi, La historia imaginada. Construcciones visuales del pasado en la Edad Moderna. Madrid: Centro de Estudios Europa Hispánica, pp. 327-358.

Schmidt, B. (2001) Innocence Abroad. The Dutch Imagination and the New World, 1570-1670. Cambridge: Cambridge University Press.

Sottas, J (1912) "Guillaume Le Testu and his work." The Mariner's Mirror. The Journal of The Society for Nautical Research, 3 (2), pp. 65-75. doi: https://doi.org/10.1080/00253359.1912.106545 79

Speziari, D. (2016) La plume et le pinceau. Nicolas Denisot, poète et artiste de la Renaissance (1515-1559). Genève: Droz.

Thomas, L. F.; Marques, A. P., and Nogueira, B. de S., Atlas Miller. Barcelona: Moleiro, 2006.
Toulouse, S. (2001) "La cartographie Normande de 1500 à 1650. La Normandie de la Renaissance: une province tournée vers la mer." In: Les normands et l'outre-mer, Actes du Congrès des Sociétés historiques et archéologiques de Normandie. Caen: Annales de Normandie, pp. 251-359.

Toulouse, S. (2007) "Marine Cartography and Navigation in Renaissance France." In: D. Woodward, ed., Cartography in the European Renaissance, Vol. 3, bk. 2, of The History of Cartography. Chicago: Chicago University Press, pp. 1550-1568.

Transylvanus, M. (1536) Il viaggio fatto dagli Spagninoli atorno a'lmondo. Venice: F. Bedford.

Van Duzer, Ch. (2015) The World for a King. Pierre Desceliers'Map of 1550. London: The British Library.

Van Groesen, M. (2008) The Representations of the Overseas World in the De Bry Collection of Voyages (1590-1634). Leiden/Boston: Brill.

Vespucci, A. (1894) The letters of Amerigo Vespucci and other documents illustrative of his career. London: Printed for the Hakluyt Society. 